\title{
Antibacterial Evaluation of Punica Granatum as Therapeutic Agents Against Multidrug Resistance Bacteria Isolated from Infertile Male's Semen
}

\author{
Khalid M. Swidan ${ }^{2, *}$ MSc.; Gamal M. El-Sherbiny ${ }^{1}$ PhD; Aziza M. Mansour ${ }^{2}$ MD; \\ Mohammed H. El haw ${ }^{1}$ PhD.; Ahmed A. Askar ${ }^{1}$ PhD. and Mohammed A. El-Badry ${ }^{1}$ PhD.
}

\author{
* Corresponding Author: \\ Khalid M. Swidan \\ khswidan_1987@yahoo.com
}

Received for publication April 30, 2020; Accepted May 21, 2020; Published online May 21, 2020.

\section{Copyright 2020 The Authors published by Al-Azhar University, Faculty of Medicine Cairo, Egypt. All rights reserved. This an open-access article distributed under the legal terms, where it is permissible to download and share the work provided it is properly cited. The work cannot be changed in any way or used commercially.}

doi: 10.21608/aimj.2020.28798.1208

${ }^{I}$ Botany and Microbiology Department, Faculty of Science (Boys), Al-Azhar University, Cairo, Egypt.

${ }^{2}$ International Islamic Center for Population Studies and Research, Al-Azhar University, Cairo, Egypt.

\begin{abstract}
Aim of work: Investigate the bacterial species from semen and evaluate susceptibility to (antibiotics and extracted from Punica granatum). Patient and methods: One hundred seminal fluid samples were collected from different males attending the fertility clinic at the International Islamic Center for Population Studies and Research, Al-Azhar University, Cairo, Egypt. All semen samples included in this study were examined for physical characters. Twenty bacterial isolates were isolated from the infected samples by agar streaking method onto MacConkey agar, mannitol salt agar and blood agar media. Separate colonies were selected for manual identification based on morphological and biochemical parameters.

Results: Three genera of bacterial isolates were obtained, and these include Escherichia coli, Staphylococcus aureus and Pseudomonas aeruginosa, with the highest counts recorded for eight isolates as Escherichia coli (40\%), eight isolates as Staphylococcus aureus (40\%) and four isolates as Pseudomonas aeruginosa (20\%). Antibiotic susceptibility for these isolates was studied and showing resistance potency. The ethanolic extracts of Punica granatum exhibited antibacterial activity against all bacterial isolates. Gas Chromatography Mass Spectroscopic analysis of Punica granatum showed that this plant has many active compounds to fight multidrug resistance bacteria in males associated with the semen of infertile males.

Conclusion: Ethyl iso-allocholate (C26H44O5) the most important and active compound against bacteria in our study. Pomegranate contains large amounts of it, antibacterial activity may be indicative of the presence of secondary metabolites. The inhibitory effect of these compounds could be related to adsorption to cell membranes, interaction with enzymes, substrate and metal ion deprivation.
\end{abstract}

Keywords: Semen; Bacterial contaminate semen; Punica granatum; G.C mass spectroscopy.

Disclosure: The authors have no financial interest to declare in relation to the content of this article. The Article Processing Charge was paid for by the authors.

Authorship: All authors have a substantial contribution to the article.

\section{INTRODUCTION}

Infertility constitutes a grave emotional and social problem in societies where great importance is attached to having children ${ }^{1}$ Male infertility refers to the inability to achieve spontaneous pregnancy in a fertile female in one year. ${ }^{2}$ A decline in the male fertility may be attributed to many factors, which include testicular failure, urogenital abnormalities, immunologic problems, varicocele, genetic abnormalities, endocrine disturbances, systemic diseases, cancer, genital tract infections, environmental agents, distorted lifestyle and gonadotoxic factor exposure. ${ }^{2}$ Infection is a powerful mechanism that can lead to sperm damage, deformity and eventually, male infertility. Genital tract infection and inflammation have been associated to $8-35 \%$ of male infertility cases. ${ }^{3}$ Spermatozoa subsequently can be affected by infections at different points in their development and maturation. Acute and chronic infections can compromise spermatogenesis, resulting in quantitative and qualitative reductions. ${ }^{4,5}$ Infections of the male genitourinary tract represent a significant health care problem and account for almost $15 \%$ of cases of male infertility. ${ }^{6}$ Among bacterial species that interact with spermatozoa are well known causative pathogens of genitourinary tract infection such as Escherichia coli, Ureaplasma urealyticum, Mycoplasma hominis and Chlamydia trachomatis. ${ }^{6,7,8}$ E. coli probably represents the most frequently 
isolated microorganism in genitourinary infections. E. coli rapidly adheres to human spermatozoa in vitro, resulting in agglutination of spermatozoa. ${ }^{9}$ Agglutination of spermatozoa was produced only by live pathogenic $E$. coli whereas killed bacteria failed to do so. ${ }^{10}$ The presence of antimicrobial components in blood and other bodily fluids, leukocytes and tissues has been known since the end of the $1800 \mathrm{~s}$ and many were reported in the first half of the 1900s. ${ }^{11}$ Attempts to improve the efficacy of available antibiotics, particularly the older and cheaper ones have been suggested. ${ }^{12}$ Medicinal plants continue to play a central role in the healthcare systems of large proportions of the world's population, particularly in developing countries, where herbal medicine has a long and uninterrupted history of use. ${ }^{13}$ This raises the prospects of obtaining novel chemotherapeutic compounds if this vastly untapped resource could be adequately explored. The prospect of obtaining drugs from plants has been demonstrated by some notable examples of important pharmaceuticals derived from plant precursors. ${ }^{14}$ The rich chemical diversity in plants has also been reported to be a promising source of antibacterial compounds raising hopes of obtaining novel antibiotics that can aid the fight against resistant infection. ${ }^{15}$ This study was conducted to evaluate antibacterial activity of Punica granatum as therapeutic agents against multidrug resistance bacterial species contaminate semen and its association with sperm quality and semen characteristics of infertile patients visiting International Islamic Center for Population Studies and Research (IICPSR), Al-Azhar University, Cairo, Egypt.

\section{PATIENT AND METHODS}

Collection of samples: seminal fluid samples were collected from 100 males attending the fertility clinic at the International Islamic Center for Population Studies and Research (IICPSR), Al-Azhar University, Cairo, Egypt. The samples were collected from patients during the period of May 2016 to October 2017. Upon collection, samples were transferred to the laboratory in a temperature around $37^{\circ} \mathrm{C}$. Semen samples are collected by masturbation after a 2 to 7 days of abstinence. ${ }^{16,17}$ The container must be clean, sterile and wide mouthed to minimize collection error. The semen specimen should be maintained at room or body temperature and examined within one hour of collection. ${ }^{17}$

Examination of samples: all semen samples included in this study were examined for physical appearance, volume, viscosity, total motility, and sperm count.

Physical examination: semen volume is by drawing the entire ejaculate up into a sterile (and warmed) graduated glass pipette. ${ }^{18}$ While the color in a normal semen sample has a homogenous, gray opalescent appearance. ${ }^{19}$ The semen odor may be affected by some foods or drugs excreted in semen. It may be offensive in some cases of genital infection or uriniferous in cases of semen contamination by urine. $^{17}$
Microscopic examination: microscopic examination includes evaluation of sperm concentration, motility and morphology.

Isolation and identification of bacterial species in semen samples: the seminal fluid samples were cultured in aseptic condition, within $1 \mathrm{~h}$ of collection on different types of enrichment and selective media. Bacteria were isolated by agar streaking method onto surface plates of MacConkey agar, mannitol salt agar and blood agar media. Then the plates were incubated aerobically and anaerobically at $37{ }^{\circ} \mathrm{C}$ for 24h. After incubation, separate bacterial colonies were picked up and subjected to purification processes by inoculating on different selective media. After purification, different colonies that appear from different samples were selected for the primary identification based on morphological and biochemical parameters 24

Automated identification of bacterial isolates by using Biomerieux Vitek 2 System: automated highly identification system for microorganisms and reproducible results as shown in multiple independent studies. With its colorimetric reagent cards, and associated hardware and software advances, VITEK 2 offers a state-of-the-art technology platform for phenotypic identification methods.

Antibiotic sensitivity of bacterial isolates: the purified bacterial isolates were subjected to evaluation of antibiotic profile using different antibiotic groups in order to select the highest antibiotic resistant bacterial isolates. Antibiotic panel was Amoxicillin-Clavulanic acid 20/10 $\mu \mathrm{g} / \mathrm{ml}$, Cefepime $\quad 30 \mu \mathrm{g} / \mathrm{ml}$, Azithromycin $15 \mu \mathrm{g} / \mathrm{ml}$, Clindamycin $2 \mu \mathrm{g} / \mathrm{ml}$, Levofloxacin $5 \mu \mathrm{g} / \mathrm{ml}$, Doxycycline $\quad 30 \mu \mathrm{g} / \mathrm{ml}$, Amikacin $30 \mu \mathrm{g} / \mathrm{ml}$, Erythromycin $15 \mu \mathrm{g} / \mathrm{ml}$, Chloramphenicol $30 \mu \mathrm{g} / \mathrm{ml}$, Cefaclor $30 \mu \mathrm{g} / \mathrm{ml}$, Aztreonam $30 \mu \mathrm{g} / \mathrm{ml}$, Ampicillin $15 \mu \mathrm{g} / \mathrm{ml}$, Cephradine $15 \mu \mathrm{g} / \mathrm{ml}$, Imipenem $10 \mu \mathrm{g} / \mathrm{ml}$, Cefotaxime $30 \mu \mathrm{g} / \mathrm{ml}$, Ceftriaxone $30 \mu \mathrm{g} / \mathrm{ml}$, Ampicillin-Sulbactam $10 / 10 \mu \mathrm{g} / \mathrm{ml}$, Piperacillin $75 \mu \mathrm{g} / \mathrm{ml}$, Cephalexin $75 \mu \mathrm{g} / \mathrm{ml}$, CefetrizoleSulbactam $75 / 30 \mu \mathrm{g} / \mathrm{ml}$ antibiotic sensitivity profile was performed according to Kirby-Bauer discdiffusion method on Mueller-Hinton agar. ${ }^{25,26}$

All strains were subculture on TSA plates and incubated over night at $37^{\circ} \mathrm{C}$. The resulting culture was passage two additional times to ensure that the organism had an optimal growth and metabolic status. ${ }^{27}$ Five to ten colonies of an overnight culture on TSA was used to inoculate $5 \mathrm{ml}$ of trypticase soy broth (TSB). Bacteria were then incubated four to five hours at $37{ }^{\circ} \mathrm{C}$, with mild shaking to promote uniformity and growth optimization.

After incubation, the culture was adjusted to a turbidity equivalent to a $0.5 \mathrm{McFarland}$ turbidity standard. Serial 1:10 dilutions in TSB was performed and $100 \mu \mathrm{l}$ of each dilution was spread over the surface of TSA plate and incubated at $37^{\circ} \mathrm{C}$ overnight to determine the viable Colony Forming Unit (CFU) of each strain. The final concentration of bacteria in 
the agar plate would approximately $10^{8} \mathrm{CFU} / \mathrm{ml}$. The plates were incubated at $37^{\circ} \mathrm{C}$ for $18-24 \mathrm{~h}$.

The experiment was carried out three times and the mean values are presented. The antimicrobial activity was evaluated by measuring the diameter of inhibition zone (mm) according to Vaghasiya and Chanda, 2010. ${ }^{28}$

Collection of plant materials: the Punica granatum medicinal plant was used in this work collected from Faculty of Agriculture, Cairo University, during December 2017.

Preparation of the alcoholic extract: about $5 \mathrm{~g}$ of airdried plant powder were re-fluxed with $2.5 \mathrm{~L}$ of $70 \%$ Ethyl alcohol for 6 hours, and then filtered. The residue powder was then washed several times with hot alcohol. The combined filtrates were concentrated under reduced pressure at $50^{\circ} \mathrm{C}$, and then used for purification and identification

Gas chromatography-mass spectrometry (GC-MS) analysis: chemical composition of plant extract was separate, purified and identified by comparison of their retention times and mass spectra with those of WILEY 09 and NIST 11 mass spectral database.

Evaluation of antibacterial activity of purified Punica granatum extract: a loop full of bacterial isolate was inoculated in $25 \mathrm{ml}$ of Muller Hinton broth in $150 \mathrm{ml}$ conical flask and incubated at room temperature on a rotary shaker for $24 \mathrm{hr}$ in order to activate the test bacteria. The final cellular concentration was $1 \times 10^{8}$ $\mathrm{CFU} / \mathrm{ml}$. The molten Mueller Hinton Agar was inoculated with $100 \mu \mathrm{l}$ of bacterial suspension and tilted well to ensure proper distribution in the plate. ${ }^{26}$ Plant extracts were dissolved in $1 \%$ dimethylsulphoxide (DMSO) for antibacterial study. Extract concentration was adjusted to $20 \mathrm{mg} / \mathrm{ml} .^{29}$ The well diffusion method was performed for the determination of antibacterial activity of plant extract against semen bacterial isolates. The well was loaded with $100 \mu \mathrm{l}$ of plant extract (well diameter: $6.0 \mathrm{~mm}$ ). Then loaded plates were incubated at $4^{\circ} \mathrm{C}$ for $2 \mathrm{~h}$. to allow the diffusion of extracts into agar and then incubated at $37^{\circ} \mathrm{C}$ for $24 \mathrm{~h}$. The diameter of the inhibition zone was measured in millimeters.

\section{RESULTS}

Collection of samples and semen parameters:

One hundred samples of semen collected from men attending the fertility clinic of the International Islamic Center for Population Studies and Research (IICPSR), were examined routinely, for normal semen characteristics and bacterial contaminate. Among total cases, 20 cases (20\%) showed at least one bacterial isolates and abnormalities range from 90 to $99 \%$ table (1)

\begin{tabular}{|c|c|c|c|c|c|}
\hline \multirow{2}{*}{ Code } & \multicolumn{3}{|c|}{ Semen Parameter } & \multirow{2}{*}{$\begin{array}{c}\text { Result } \\
\text { (growth) }\end{array}$} \\
\cline { 2 - 5 } & $\begin{array}{c}\text { Count } \\
\text { million per ml }\end{array}$ & Motility $\%$ & Abnormal $\%$ & Pus Cells & +ve \\
\hline $\mathbf{1}$ & 3 & 28 & 99 & $6-10$ & $+\mathrm{ve}$ \\
\hline $\mathbf{2}$ & 5 & 15 & 97 & $10-12$ & $+\mathrm{ve}$ \\
\hline $\mathbf{3}$ & 65 & 8 & 95 & $8-10$ & $+\mathrm{ve}$ \\
\hline $\mathbf{4}$ & 1 & 18 & 90 & $10-12$ & $+\mathrm{ve}$ \\
\hline $\mathbf{5}$ & 9 & 8 & 93 & $7-9$ & $+\mathrm{ve}$ \\
\hline $\mathbf{6}$ & 4 & 13 & 97 & $9-16$ & $+\mathrm{ve}$ \\
\hline $\mathbf{7}$ & 79 & 17 & 99 & $10-12$ & $+\mathrm{ve}$ \\
\hline $\mathbf{8}$ & 14 & 18 & 90 & $12-14$ & $+\mathrm{ve}$ \\
\hline $\mathbf{9}$ & 19 & 5 & 92 & $12-16$ & $+\mathrm{ve}$ \\
\hline $\mathbf{1 0}$ & 2 & 19 & 97 & $18-20$ & $+\mathrm{ve}$ \\
\hline $\mathbf{1 1}$ & 10 & 24 & 90 & $8-12$ & $+\mathrm{ve}$ \\
\hline $\mathbf{1 2}$ & 8 & 10 & 92 & $8-10$ & $+\mathrm{ve}$ \\
\hline $\mathbf{1 3}$ & 3 & 26 & 96 & $10-12$ & $+\mathrm{ve}$ \\
\hline $\mathbf{1 4}$ & 15 & 27 & 93 & $15-18$ & $+\mathrm{ve}$ \\
\hline $\mathbf{1 5}$ & 1 & 30 & 97 & $18-20$ & $+\mathrm{ve}$ \\
\hline $\mathbf{1 6}$ & 2 & 9 & 91 & $12-16$ & $+\mathrm{ve}$ \\
\hline $\mathbf{1 7}$ & 5 & 17 & 93 & $16-20$ & $+\mathrm{ve}$ \\
\hline $\mathbf{1 8}$ & 89 & 9 & 93 & $8-12$ & $+\mathrm{ve}$ \\
\hline $\mathbf{1 9}$ & 3 & 17 & 90 & & \\
\hline $\mathbf{2 0}$ & 12 & 30 & 94 & & \\
\hline
\end{tabular}

Table 1: Semen parameter of samples used to isolate bacterial species

Isolation of bacteria species from the collected semen samples:

Twenty bacterial isolates were isolated from the collecting samples by agar streaking method onto MacConkey agar, mannitol salt agar and blood agar media. A total of 20 bacterial isolates were identified. The overall prevalence of Gram-negative bacteria was $60 \%(12 / 20)$ and for Gram positive bacteria was $40 \%(8 / 20)$. The identification results were evident it, predominate bacterial isolates were found belong to
E. coli (40\%), Staphylococcus aureus (40\%) Pseudomonas aeruginosa (20\%) from total bacterial isolates as shown in figure (1).

Antibiotics susceptibility of bacterial isolates: Antibiotic sensitivity profile of bacterial isolates was performed in order to select the highest resistant bacteria against major of commercial antibiotic groups available at the market as showing in table (1). 

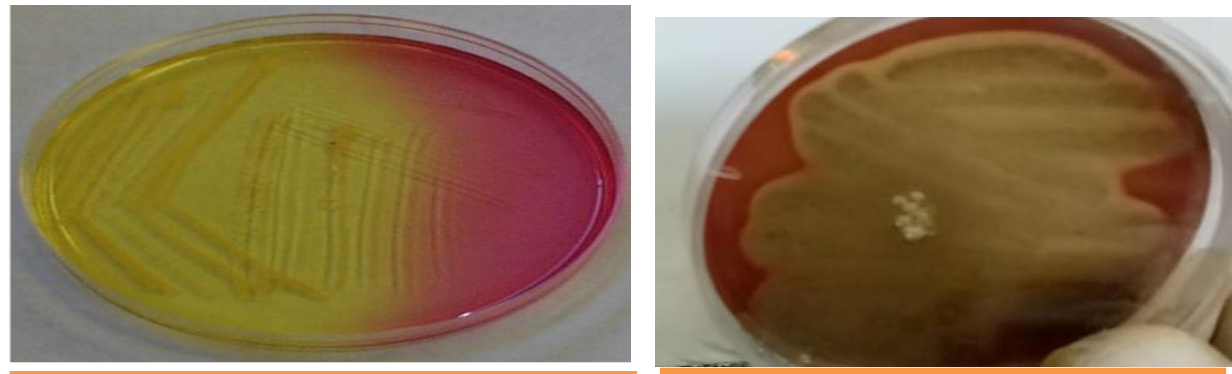

Staphylococcus aureus on mannitol salt agar

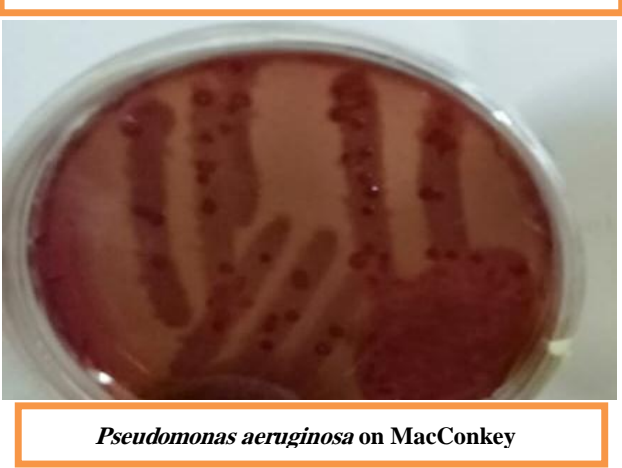

Pseudomonas aeruginosa on blood agar

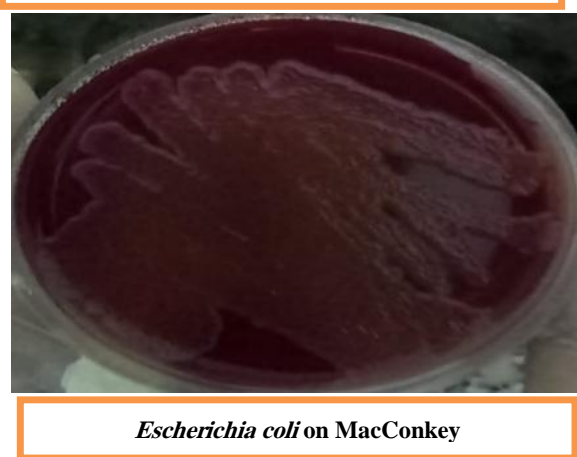

Fig.1: Some bacterial species isolated from semen samples on MacConkey agar, blood agar media and Mannitol salt agar.

A total of $100 \%$ of Escherichia coli. isolates were resistant to (clindamycin and piperacillin) and $87.5 \%$ to erythromycin, ampicillin and cephalexin while Staphylococcus aureus and Pseudomonas aeruginosa isolates were resistance to amoxicillin/clavulanic acid, cefepime and ampicillin with ratio $100 \%$ table (2).
Antibacterial activity of Punica granatum extracts against semen bacterial isolates:

Results showing that, the most potent extract from Punica granatum which give highest inhibition zones ranging from 18 to $36 \mathrm{~mm}$ against bacterial species isolated from semen samples table (3).

\begin{tabular}{|c|l|c|c|c|}
\hline \multirow{2}{*}{ No } & \multicolumn{1}{|c|}{ Bacterial species } & Punica granatum & Solvent & Levofloxacin \\
\hline 1 & Escherichia coli- 01 & 25 & NA & 35 \\
\hline 2 & Escherichia coli-04 & 30 & NA & 30 \\
\hline 3 & Escherichia coli-06 & 18 & NA & 13 \\
\hline 4 & Escherichia coli-09 & 20 & NA & 10 \\
\hline 5 & Escherichia coli-11 & 22 & NA & 20 \\
\hline 6 & Escherichia coli-14 & 28 & NA & 10 \\
\hline 7 & Escherichia coli-16 & 23 & NA & 32 \\
\hline 8 & Escherichia coli-19 & 26 & NA & 9 \\
\hline 9 & Staphylococcus aureus-02 & 20 & NA & 25 \\
\hline 10 & Staphylococcus aureus-03 & 16 & NA & 25 \\
\hline 11 & Staphylococcus aureus-07 & 30 & NA & 30 \\
\hline 12 & Staphylococcus aureus-08 & 25 & NA & 20 \\
\hline 13 & Staphylococcus aureus-12 & 20 & NA & 26 \\
\hline 14 & Staphylococcus aureus-13 & 20 & NA & 26 \\
\hline 15 & Staphylococcus aureus-17 & 22 & NA & 10 \\
\hline 16 & Staphylococcus aureus-18 & 18 & NA & 28 \\
\hline 17 & Pseudomonas aeruginosa-05 & 35 & NA & 31 \\
\hline 18 & Pseudomonas aeruginosa-10 & 32 & NA & 26 \\
\hline 19 & Pseudomonas aeruginosa-15 & 31 & NA & 25 \\
\hline 20 & Pseudomonas aeruginosa-20 & 36 & 34 \\
\hline
\end{tabular}

Table 3: Antibacterial activity of Punica granatum extracts against semen bacterial isolates. 


\begin{tabular}{|c|c|c|c|c|}
\hline \multirow{2}{*}{\multicolumn{2}{|c|}{$\begin{array}{ll}\text { Bacteria isolates } \\
\text { Antibiotics }\end{array}$}} & Escherichia coli & Staphylococcus aureus & Pseudomonas aeruginosa \\
\hline & & N. $(\%)$ & N. $(\%)$ & \begin{tabular}{|l|} 
N. $(\%)$ \\
\end{tabular} \\
\hline \multirow{3}{*}{$\begin{array}{c}\text { Amoxicillin/Clavulanic acid } \\
\text { AMC }(20 / 10 \mu \mathrm{g})\end{array}$} & $\mathrm{R}$ & $6(30.0 \%)$ & $8(40.0 \%)$ & $4(20.0 \%)$ \\
\hline & I & $1(5.0 \%)$ & $0(0.0 \%)$ & $0(0.0 \%)$ \\
\hline & $\mathrm{S}$ & $1(5.0 \%)$ & $0(0.0 \%)$ & $0(0.0 \%)$ \\
\hline \multirow{3}{*}{$\begin{array}{c}\text { Cefepime } \\
\text { FEP(30 }(3 \mathrm{~g})\end{array}$} & $\mathrm{R}$ & $5(25.0 \%)$ & $8(40.0 \%)$ & $4(20.0 \%)$ \\
\hline & I & $1(5.0 \%)$ & $0(0.0 \%)$ & $4(20.0 \%)$ \\
\hline & $\mathrm{S}$ & $2(10.0 \%)$ & $0(0.0 \%)$ & $0(0.0 \%)$ \\
\hline \multirow{3}{*}{$\begin{array}{l}\text { Azithromycin } \\
\text { AZM(15 } \mu \mathrm{g})\end{array}$} & $\mathrm{R}$ & $2(10.0 \%)$ & $0(0.0 \%)$ & $1(5.0 \%)$ \\
\hline & $\mathrm{I}$ & $3(15.0 \%)$ & $1(5.0 \%)$ & $0(0.0 \%)$ \\
\hline & $\mathrm{S}$ & $3(15.0 \%)$ & $7(35.0 \%)$ & $3(15.0 \%)$ \\
\hline \multirow{3}{*}{$\begin{array}{l}\text { Clindamycin. } \\
\text { DA }(2 \mu \mathrm{g})\end{array}$} & $\mathrm{R}$ & $8(40.0 \%)$ & $0(0.0 \%)$ & $4(20.0 \%)$ \\
\hline & I & $0(0.0 \%)$ & $3(15.0 \%)$ & $0(0.0 \%)$ \\
\hline & $\mathrm{S}$ & $0(0.0 \%)$ & $5(25.0 \%)$ & $0(0.0 \%)$ \\
\hline \multirow{3}{*}{$\begin{array}{l}\text { Levofloxacin } \\
\text { LEV }(5 \mu g)\end{array}$} & $\mathrm{R}$ & $4(20.0 \%)$ & $0(0.0 \%)$ & $0(0.0 \%)$ \\
\hline & I & $0(0.0 \%)$ & $0(0.0 \%)$ & $1(5.0 \%)$ \\
\hline & $\mathrm{S}$ & $4(20.0 \%)$ & $8(40.0 \%)$ & $3(15.0 \%)$ \\
\hline \multirow{3}{*}{$\begin{array}{l}\text { Doxycycline } \\
\text { DO }(30 \mu g)\end{array}$} & $\mathrm{R}$ & $1(5.0 \%)$ & $0(0.0 \%)$ & $2(10.0 \%)$ \\
\hline & I & $3(15.0 \%)$ & $0(0.0 \%)$ & $1(5.0 \%)$ \\
\hline & $\mathrm{S}$ & $4(20.0 \%)$ & $8(40.0 \%)$ & $1(5.0 \%)$ \\
\hline \multirow{3}{*}{$\begin{array}{l}\text { Erythromycin } \\
\text { E(15 } \mu \mathrm{g})\end{array}$} & $\mathrm{R}$ & $7(35.0 \%)$ & $1(5.0 \%)$ & $4(20.0 \%)$ \\
\hline & $\mathrm{I}$ & $0(0.0 \%)$ & $4(20.0 \%)$ & $0(0.0 \%)$ \\
\hline & $\mathrm{S}$ & $1(5.0 \%)$ & $3(15.0 \%)$ & $0(0.0 \%)$ \\
\hline \multirow{3}{*}{$\begin{array}{l}\text { Chloramphenicol } \\
\text { C }(30 \mu \mathrm{g})\end{array}$} & $\mathrm{R}$ & $1(5.0 \%)$ & $0(0.0 \%)$ & $3(15.0 \%)$ \\
\hline & I & $0(0.0 \%)$ & $0(0.0 \%)$ & $0(0.0 \%)$ \\
\hline & $\mathrm{S}$ & $7(35.0 \%)$ & $8(40.0 \%)$ & $1(5.0 \%)$ \\
\hline \multirow{3}{*}{$\begin{array}{c}\text { Cefaclor } \\
\text { CEC }(30 \mu g)\end{array}$} & $\mathrm{R}$ & $6(30.0 \%)$ & $6(30.0 \%)$ & $4(20.0 \%)$ \\
\hline & I & $1(5.0 \%)$ & $1(5.0 \%)$ & $0(0.0 \%)$ \\
\hline & S & $1(5.0 \%)$ & $1(5.0 \%)$ & $0(0.0 \%)$ \\
\hline \multirow{3}{*}{$\begin{array}{l}\text { Aztreonam } \\
\text { ATM(30 } \mu g)\end{array}$} & $\mathrm{R}$ & $6(30.0 \%)$ & $8(40.0 \%)$ & $1(5.0 \%)$ \\
\hline & $\mathrm{I}$ & $0(0.0 \%)$ & $0(0.0 \%)$ & $1(5.0 \%)$ \\
\hline & S & $2(10.0 \%)$ & $0(0.0 \%)$ & $2(10.0 \%)$ \\
\hline \multirow{3}{*}{ 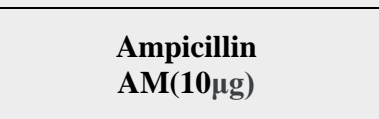 } & $\mathrm{R}$ & $7(35.0 \%)$ & $8(40.0 \%)$ & $4(20.0 \%)$ \\
\hline & I & $0(0.0 \%)$ & $0(0.0 \%)$ & $0(0.0 \%)$ \\
\hline & $\mathrm{S}$ & $1(5.0 \%)$ & $0(0.0 \%)$ & $0(0.0 \%)$ \\
\hline \multirow{3}{*}{$\begin{array}{l}\text { Cephradine. } \\
\text { CE(30 } \mu \mathrm{g})\end{array}$} & $\mathrm{R}$ & $6(30.0 \%)$ & $6(30.0 \%)$ & $4(20.0 \%)$ \\
\hline & I & $1(5.0 \%)$ & $2(10.0 \%)$ & $0(0.0 \%)$ \\
\hline & $S$ & $1(5.0 \%)$ & $0(0.0 \%)$ & $0(0.0 \%)$ \\
\hline \multirow{3}{*}{$\begin{array}{l}\text { Amikacin } \\
\mathbf{A K}(30 \mu \mathrm{g})\end{array}$} & $\mathrm{R}$ & $2(10.0 \%)$ & $2(10.0 \%)$ & $0(0.0 \%)$ \\
\hline & I & $1(5.0 \%)$ & $1(5.0 \%)$ & $0(0.0 \%)$ \\
\hline & $\mathrm{S}$ & $5(25.0 \%)$ & $5(25.0 \%)$ & $4(20.0 \%)$ \\
\hline \multirow{3}{*}{$\begin{array}{l}\text { Imipenem } \\
\text { IPM(10 } \mu \mathrm{g})\end{array}$} & $\mathrm{R}$ & $3(15.0 \%)$ & $0(0.0 \%)$ & $1(5.0 \%)$ \\
\hline & $\mathrm{I}$ & $0(0.0 \%)$ & $1(5.0 \%)$ & $0(0.0 \%)$ \\
\hline & $S$ & $5(25.0 \%)$ & $7(35.0 \%)$ & $3(15.0 \%)$ \\
\hline \multirow{3}{*}{$\begin{array}{l}\text { Cefotaxime } \\
\text { CTX }(30 \mu g)\end{array}$} & $\mathrm{R}$ & $5(25.0 \%)$ & $5(25.0 \%)$ & $4(20.0 \%)$ \\
\hline & $\mathrm{I}$ & $2(10.0 \%)$ & $3(15.0 \%)$ & $0(0.0 \%)$ \\
\hline & $\mathrm{S}$ & $1(5.0 \%)$ & $0(0.0 \%)$ & $0(0.0 \%)$ \\
\hline & $\mathrm{R}$ & $5(25.0 \%)$ & $5(25.0 \%)$ & $4(20.0 \%)$ \\
\hline Ceftriaxone. & $\mathrm{I}$ & $2(10.0 \%$ & $2(10.0 \%)$ & $0(0.0 \%)$ \\
\hline & $\mathrm{S}$ & $1(5.0 \%)$ & $1(5.0 \%)$ & $0(0.0 \%)$ \\
\hline & $\mathrm{R}$ & $3(15.0 \%)$ & $4(20.0 \%)$ & $4(20.0 \%)$ \\
\hline Ampicillin - Sulbactam & I & $2(10.0 \%)$ & $2(10.0 \%)$ & $0(0.0 \%)$ \\
\hline & $\mathrm{S}$ & $3(15.0 \%)$ & $2(10.0 \%)$ & $0(0.0 \%)$ \\
\hline & $\mathrm{R}$ & $8(40.0 \%)$ & $7(35.0 \%)$ & $4(20.0 \%)$ \\
\hline Piperacillin & $\mathrm{I}$ & $0(0.0 \%)$ & $1(5.0 \%)$ & $0(0.0 \%)$ \\
\hline & $\mathrm{S}$ & $0(0.0 \%)$ & $0(0.0 \%)$ & $0(0.0 \%)$ \\
\hline & $\mathrm{R}$ & $7(35.0 \%)$ & $7(35.0 \%)$ & $4(20.0 \%)$ \\
\hline Cephalexin & I & $0(0.0 \%)$ & $0(0.0 \%)$ & $0(0.0 \%)$ \\
\hline & $\mathrm{S}$ & $1(5.0 \%)$ & $1(5.0 \%)$ & $0(0.0 \%)$ \\
\hline & $\mathrm{R}$ & $4(20.0 \%)$ & $5(25.0 \%)$ & $2(10.0 \%)$ \\
\hline Cefoperazone - Sulbactum & I & $0(0.0 \%)$ & $3(15.0 \%)$ & $2(10.0 \%)$ \\
\hline 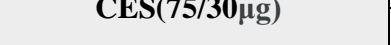 & $\mathrm{S}$ & $4(20.0 \%)$ & $0(0.0 \%)$ & $0(0.0 \%)$ \\
\hline
\end{tabular}

Table 2: Antibiotics profile of semen bacterial isolates. 
Gas Chromatography Mass:

Ethanolic extract was found to have a wide range of bioactive compounds like alkaloids, coumarins, flavonoids, proteins, phenols and tannins. Gas chromatography mass spectroscopic analysis and the data obtained could be interpreting the active ingredients with expected chemical formula and molecular weight for the active compound. Ethyl isoallocholate is one of the most important compounds obtained from $P$. granatum peel extract with molecular weight $\left(\mathrm{C}_{26} \mathrm{H}_{44} \mathrm{O}_{5}\right)$ and has significant effect on growth of bacterial isolates from semen samples.

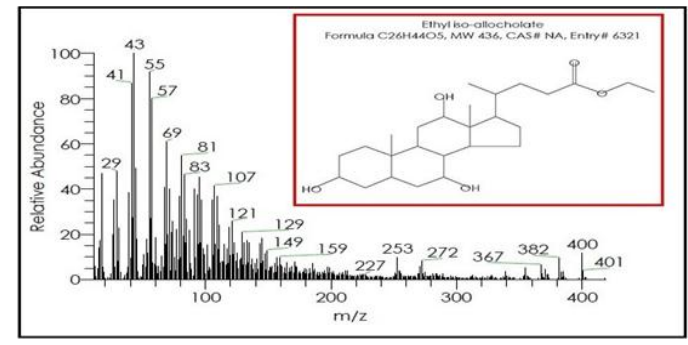

Fig. 2: Ethyl iso-allocholate $\left(\mathrm{C}_{26} \mathrm{H}_{44} \mathrm{O}_{5}\right)$ obtained from GC mass spectroscopy

\section{DISCUSSION}

Male urogenital tract infection is an important cause of men infertility. The etiological role of infections in male infertility has been paid attention in recent years. Asymptomatic bacteriospermia may play a major role. ${ }^{30,31}$ Infectious processes may lead to deterioration of spermatogenesis, impairment of sperm function and obstruction of the seminal tract. ${ }^{32}$

Many studies have examined the impact of genital tract infections and bacterial semen contamination in male fertility; however, the putative detrimental effect of bacteria on the sperm quality is still controversial. Microorganisms can affect the male reproductive function directly, causing the agglutination of motile sperm, reducing the ability of acrosome reaction and causing alterations in cell morphology-and indirectly, through the production of reactive oxygen species generated by the inflammatory response to the infection. ${ }^{33}$

The present study aims to isolate and identify different bacterial isolates collected from semen of infertile males attending infertility center at International Islamic center for population studies and Research, Al-Azhar University. Medicinal plants extract was used as an alternative therapeutic agent targeting these isolates. One hundred samples of semen were collected and examined for normal semen characteristics and bacterial count. Among total cases, 20 cases $(20 \%)$ showed at least one pathogen. Three genera of bacterial isolates were obtained, and these include Escherichia coli, Staphylococcus aureus and Pseudomonas aeruginosa, with the highest counts recorded for the genera Escherichia coli 8(40\%), Staphylococcus aureus $8(40 \%)$ and Pseudomonas aeruginosa $4(20 \%)$
Our study was in agreement with Emokpae et al., $2009{ }^{34}$ reported that presence of $S$. aureus should not be ignored as it can lead to decrease in the number of spermatozoa, the suppression of their motility, changes in their morphology and fertilizing capacity, $S$. aureus could to be the dominant flora in infertile men with a significant decrease in sperm motility.

Our study was in agreement with previous studies examined the impact of genital tract infections and bacterial semen contamination in male fertility and should that microorganisms can affect the male reproductive function directly, causing the agglutination of motile sperm, reducing the ability of acrosome reaction and causing alterations in cell morphology-and indirectly, through the production of reactive oxygen species generated by the inflammatory response to the infection. ${ }^{33}$

Alternatively, effect of antimicrobial agents on bacteria was also observed. Treatment of cultured bacteria with different groups of antibiotics abolished the effect. This indicates that must be some adhesion sites on spermatozoa to which $E$. coli binds. The mechanisms by which $E$. coli affect sperm functions have not yet been identified. ${ }^{35}$

Interference of $E$. coli with these receptors may influence the motility and viability. Other authors reported similar observations concerning sperm motility and agglutination after incubation with $E$. coli. We suggest in agreement with previous study that $E$. coli spermatozoa-interaction may be a twostep process: i.e. adhesion to and subsequent destruction of the sperm membrane. This mechanism may account for any inhibitory effects of $E$. coli infection on male fertility. It is speculative whether the same mechanisms are also responsible for impaired male fertility in cases of genitourinary infections. ${ }^{35}$

The goal of the treatment of semen infection is to control the spread of infection and provide symptom relief, which can usually be achieved without the use of antibiotics and other antimicrobial agents. Therefore, all bacterial isolates in this study were tested for susceptibilities to antibiotics and plant extract with the intention of determining the most effective drug for all bacterial isolated. The result obtained revealed that the most potent antibiotics against all bacterial isolates were found chloramphenicol, imipenem and levofloxacin. While ampicillin and piperacillin give high resistant ratio.

For the prevention of the emergence of resistant microorganisms commonly used plant extracts. The in vitro antibacterial activity of $P$. grantum was studied against bacterial isolates. The aqueous and ethanolic extracts exhibited antibacterial activity against all bacterial isolates with inhibition zone ranged from 16 to $36 \mathrm{~mm}$.

As previous reports, $P$. grantum contains chemical constituents like, ellagitannins, phenols, tannins, punicic acid, flavonoids, anthocyanins, estrogenic flavonoids and flavones, P. grantum extract have antibacterial activity. ${ }^{36}$

Ethyl iso-allocholate $\left(\mathrm{C}_{26} \mathrm{H}_{44} \mathrm{O}_{5}\right)$ the most important and active compound against bacteria in our study. Pomegranate contains large amounts of it, 
antibacterial activity may be indicative of the presence of secondary metabolites. The inhibitory effect of these compounds could be related to adsorption to cell membranes, interaction with enzymes, substrate and metal ion deprivation. ${ }^{37}$

According to World Health Organization reported that approximately $75-80 \%$ of the world's population uses plant medicines either in part or entirely. Growing numbers of American health care consumers are turning to plant medicines for many reasons - low cost and seeking natural alternatives with fewer side effects are commonly cited. ${ }^{38}$

\section{CONCLUSION}

In conclusion, the present study showed that the microbiological investigation should be performed, as a routine test, to all infertile men attending to infertility clinics. It should be noticed that presence of urogenital tract infection and inflammation must be eradicated by antibiotic and anti- inflammatory treatment, especially before using Assisted Reproductive Techniques (ART).

\section{REFERENCES}

1. Caldwell JC and Caldwell P: "A Theory of Fertility. From High Plateau to Destabilization" Population and Development Review. 1978; Vol. 4, No. 4, pp 553-7.

2. Rana $\mathrm{K}$, Vander $\mathrm{H}$, Bhandari $\mathrm{P}$, et al Microorganisms and male infertility: possible pathophysiological mechanisms. Adv Clin Med Microbiol. 2016; 1: 1-10.

3. Sushila K, Arvind S, Vijay P, et al. Escherichia coli attaches to human spermatozoa: Affecting sperm parameters. Arch Appl Sci Res. 2001; 3: $618-23$.

4. Golshani M, Taheri S, Eslami G, et al. Genital tract infection in asymptomatic infertile men and its effect on semen quality. Ir J Publ Health. 2006; 35:81-4.

5. Khalili MB, Sharifi-Yazdi MK. The effect of bacterial infection on the quality of human's spermatozoa. Ir J Publ Health. 2001; 30:119-22.

6. Gdoura R, Kchaou W, Chaari C, et al. Ureaplasma urealyticum, Ureaplasma parvum, Mycoplasma hominis and Mycoplasma genitalium infections and semen quality of infertile men. BMC Infect Dis. 2007; 7:129-37.

7. Kohn FM, Erdmann I, Oeda T, et al. Influence of urogenital infections on sperm functions. Andrologia. 1998; 30:73-80.

8. Hosseinzadeh S, Brewis IA, Eley A, et al. Coincubation of human spermatozoa with Chlamydia trachomatiss erovar E causes premature sperm death. Human Reprod. 2001; 16:293-9.
9. Diemer T, Huwe P, Ludwig M, et al. Influence of autogenous leucocytes and Escherichia coli on sperm motility parameters in vitro. Andrologia. 2003; 35:100-105.

10. Liu JH, Li HY, Cao ZG, et al. Influence of several uropathogenic microorganisms on human sperm motility parameters in vitro. Asian $J$ Androl. 2002; 4:179-82.

11. Sharnes RC and Watson DW. "Antimicrobial factors of normal tissues and fluid". Bacterial Rev, 2006; 21(4): p 273-94.

12. Lomovskaya O and Bostian KA. Practical applications and feasibility of eux pump inhibitors in the clinic-a vision for applied use. Biochem. PharmIacol. 2006; 71:910-918.

13. Koduru S, Grierson DS and Afolayan AJ. Ethnobotanical information of medicinal plants used for treatment of cancer in the Eastern Cape Province, South Africa. Curr Sci. 2007; 92: 9068.

14. Raskin I, Ribnicky DM, Komarnytsky S, et al. Plants and human health in the twenty-first century. Trends Biotech. 2002; 20:522-31.

15. Smith ECJ, Williamson EM, Wareham N, et al. Antibacterials and modulators of bacterial resistance from the immature cones of Chamaecyparis lawsoniana. Phytochem. 2007; 68:210-17.

16. Mallidis, C. Necrospermia and chronic spinal cord injury. Fertil. Steril. 2003; 74:221-7.

17. WHO. Laboratory manual for the examination and processing of human semen (5th ${ }^{\text {ed) }}$, WHO Press, World Health Organization: 2010; 10-50.

18. Rouge M. Appearance of semen and sperm concentration in Rouge, M. (ed.) collection and evaluation of semen, Black well science ltd. London: 2002; 42-68.

19. Campble UE. Initial basic laboratory evaluation. In: Walsh, P.C.; Ratik, A.B. and Vaghan, A. (eds.): Campbell's Urology (8thed), Saunde Company, Philadelphia, London, Toronto. 2002; $1250-88$

20. Hancock P. and Mc Laughlin E. British Andrology Society guidelines for the assessment of post vasectomy semen samples. J. Clin. Pathol. 2002; 21: 55-812.

21. Jequier AM. Male infertility: A clinical guides (2nded). Anatomy and physiology of the male reproductive system, published by Cambridge university press, New York: 2011; 19.

22. Kruger TF and Frank DR. Atlas of Human sperm morphology. Taylor\& Francis group. London New York. 2004; 43-74. 
23. Mortimer D and Menkveld R. Sperm morphology assessment-historical perspectives and current opinions. J. Androl; 2001; 21: 22192.

24. Harley JP and Prescott LM. Laboratory Exercises in Microbiology. 5th Edition, The McGraw-Hill Companies. 2002.

25. Mamishi S., Movahedi Z., Norouzi S., et al. Disseminated BCG asa unique feature of an infant with severe combined immunodeficiency. Turk J Pediatr. 2011; 53(3):328-32.

26. Clinical and Laboratory Standards Insitute (CLSI). Performance Standards for Antimicrobial Susceptebility Testing: Nineteenth Informational Supplement M100- 2009; S19.

27. National Committee for Clinical Laboratory Standards. Performance standards for antimicrobial disk susceptibility tests. Approved standard M2-A6. Wayne, Pa: National Committee for Clinical Laboratory Standards. 1997.

28. Vaghasiya Y. and Chanda S. Antimicrobial and Tree Radical Scavenging Activity of Different Solvent Extracts of Mangifera indica L. Seeds. Research Journal of Microbiology. 2010; 24, 217-223.

29. Al-Fatimi M, Wurster M, Schröder G, et al. Antioxidant, antimicrobial and cytotoxic activities of selected medicinal plants from Yemen. J Ethnopharmacol. 2007; May 22; 111(3):657-66.

30. Askienazy-Elbhar. Male genital tract infection: The point of view of the bacteriologist. Gynecol Obstet Fertil. 2005; 33: 691-7.
31. Li HY and Liu JH. Influence of male genital bacterial infection on sperm function. Zhonghoa Nan KeXue.2002; 8:442-4.

32. Keck C, Gerber-Schafer C, Clad A, et al. Seminal tract infections: Impact on male fertility and treatment options. Hum Reprod Update.1998; 4:891-903.

33. Moretti E, Serena C, Natale F, et al. The presence of bacteria species in semen and sperm quality. $J$ Assist Reprod Genet. 2009; 26:47-56.

34. Emokpae MA, Uadia PO and Sadiq NM. Contribution of bacterial infection to male infertility in Nigerians. J. Health and Allied Sci. 2009; 8:1-5.

35. Kala S, Arvind S, Vijay P, et al. Escherichia coli attaches to human spermatozoa: Affecting sperm parameters. Arch. Appl Sci Res. 2011; 3:618-623.

36. Fateh MV, Ahmed S, Ali M, et al. A review on the medicinal importance of pomegranate. $J$ Pharm sci. 2013; 3(4): 23- 5. doi:10.5530/rjps.2013.4.3.

37. Calbert A. Antimicrobial properties of tannins Phytochemistry. 1991; 30 (12): 3875-83.

38. Babb DA, Pemba L, Seatlanyane P, et al. Use of traditional medicine in the era of antiretroviral therapy: Experience from South Africa. E J LAS. Med. Gen. Med.2004; 6:10640. 